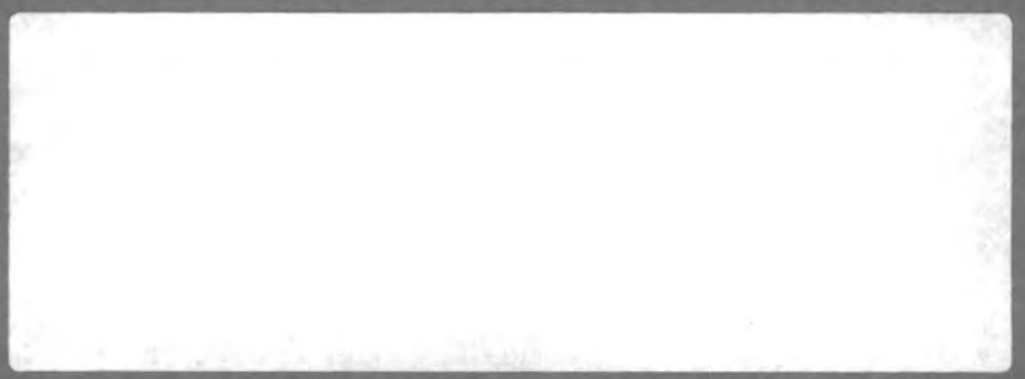

Assessment of Effectiveness of

Geologic Isolation Systems

PNL-2859

UC-70

Preliminary Subsurface

Hydrologic Considerations:

Columbia River Plateau

Physiographic Province

M. D. Veatch

Shannon and Wilson, Inc.

\title{
April 1980
}

Prepared for the

Office of Nuclear Waste Isolation under its Contract with the

U.S. Department of Energy

Pacific Northwest Laboratory

Operated for the U.S. Department of Energy

by Battelle Memorial Institute 


\title{
NOTICE
}

This report was prepared as an account of work sponsored by the United States Government. Neither the United States nor the Department of Energy, nor any of their employees, nor any of their contractors, subcontractors, or their employees, makes any warranty, express or implied, or assumes any legal liability or responsibility for the accuracy, completeness or usefulness of any information, apparatus, product or process disclosed, or represents that its use would not infringe privately owned rights.

The views, opinions and conclusions contained in this report are those of the contractor and do not necessarily represent those of the United States Government or the United States Department of Energy.

\author{
PACIFIC NORTHWEST LABORATORY \\ operated by \\ BATTELLE \\ for the \\ UNITED STATES DEPARTMENT OF ENERGY \\ Under Contract DE-AC06-76RLO 1830
}

\author{
Printed in the United States of America \\ Available from \\ National Technical Information Service \\ United States Department of Commerce \\ 5285 Port Royal Road \\ Springfield, Virginia 22151
}

Price: Printed Copy $\$$

$\because$ Microfiche $\$ 3.00$

NTIS

-Pages Selling Price

$\begin{array}{ll}001-025 & \$ 4.00 \\ 026-050 & \$ 4.50 \\ 051-075 & \$ 5.25 \\ 076-100 & \$ 6.00 \\ 101-125 & \$ 6.50 \\ 126-150 & \$ 7.25 \\ 151-175 & \$ 8.00 \\ 176-200 & \$ 9.00 \\ 201-225 & \$ 9.25 \\ 226-250 & \$ 9.50 \\ 251-275 & \$ 10.75 \\ 276-300 & \$ 11.00\end{array}$


PRELIMINARY SUBSURFACE HYDROLOGIC CONSIDERATIONS: COLUMBIA RIVER PLATEAU PHYSIOGRAPHIC PROVINCE

M. D. Veatch

Shannon and Wilson, Inc.

Apri1 1980

Prepared for the

Office of Nuclear Waste Isolation

Under its Contract with the

U.S. Department of Energy

Pacific Northwest Laboratory

Richland, Washington 99352 



\section{PREFACE}

Associated with commercial nuclear power production in the United States is the generation of potentially hazardous radioactive waste products. The Department of Energy (DOE), through the National Waste Terminal Storage (NWTS) Program and the Office of Nuclear Waste Isolation (ONWI), is seeking to develop nuclear waste isolation systems in geologic formations. These underground waste isolation systems will preclude contact with the biosphere of waste radionuclides in concentrations which are sufficient to cause deleterious impact on humans or their environments. Comprehensive analyses of specific isolation systems are needed to assess the post-closure expectations of the systems. The Assessment of Effectiveness of Geologic Isolation Systems (AEGIS) Program has been established for developing the capability of making those analyses.

Among the analyses required for the system evaluation is the detailed assessment of the post-closure performance of nuclear waste repositories in geologic formations. This assessment is concerned with aspects of the nuclear program which previously have not been addressed. The nature of the isolation systems (e.g., involving breach scenarios and transport through the geosphere) and the great length of time for which the wastes must be controlled dictate the development, demonstration, and application of novel assessment capabilities. The assessment methodology must be thorough, flexible, objective, and scientificaliy defensible. Furthermore, the data utilized must be accurate, documented, reproducible, and based on sound scientific principles.

The current scope of AEGIS is limited to long-term, post-closure analyses. It excludes the consideration of processes that are induced by the presence of the wastes, and it excludes the consideration of nuclear waste isolation in media other than geologic formations. The near-field/near-term aspects of geologic repositories are being considered by ONWI/DOE under separate programs. They will be integrated with the AEGIS methodology for the actual sitespec ific repository safety anaiyses. 
The assessment of repository post-closure safety has two basic components:

- identification and analyses of breach scenarios and the pattern of events and processes causing each breach;

- identification and analyses of the environmental consequences of radionuclide transport and interactions subsequent to a repository breach.

The Release Scenario task is charged with identifying and analyzing breach scenarios and their associated patterns of events and processes.

The Release Scenario task is concerned with evaluating the geologic system surrounding an underground repository and describing the phenomena which alone or in concert could perturb the system and possible cause a loss of repository integrity. Output from the Release Scenario task will establish the boundary conditions of the geology and hydrology surrounding the repository at the time of an identified breach. These bounding conditions will be used as input for the consequence analysis task, which will employ sophisticated hydrological transport models to evaluate the movement of radionuclides through the groundwater system to the biosphere.

AEGIS has contracted with a number of consultants to obtain expert scientific opinion about the geologic processes which could affect an underground repository. The consultants were asked to specify processes and events which might affect potential repository sites and, if possible, to give rates and probabilities for those phenomena. The consultants have also been involved with the description of the system interactions and synergisms.

This report contains information obtained by one of the AEGIS consultants during the FY-1978 research effort. The research described in this document is being continued during FY-1979 and FY-1980. Because of the ongoing nature of the Release Scenario methodology development effort, many of the results and conclusions outlined in this report are subject to change upon completion of additional research and analyses. The information contained in this report is based upon the expert opinion of an individual consultant and should be treated as such. 
CONTENTS

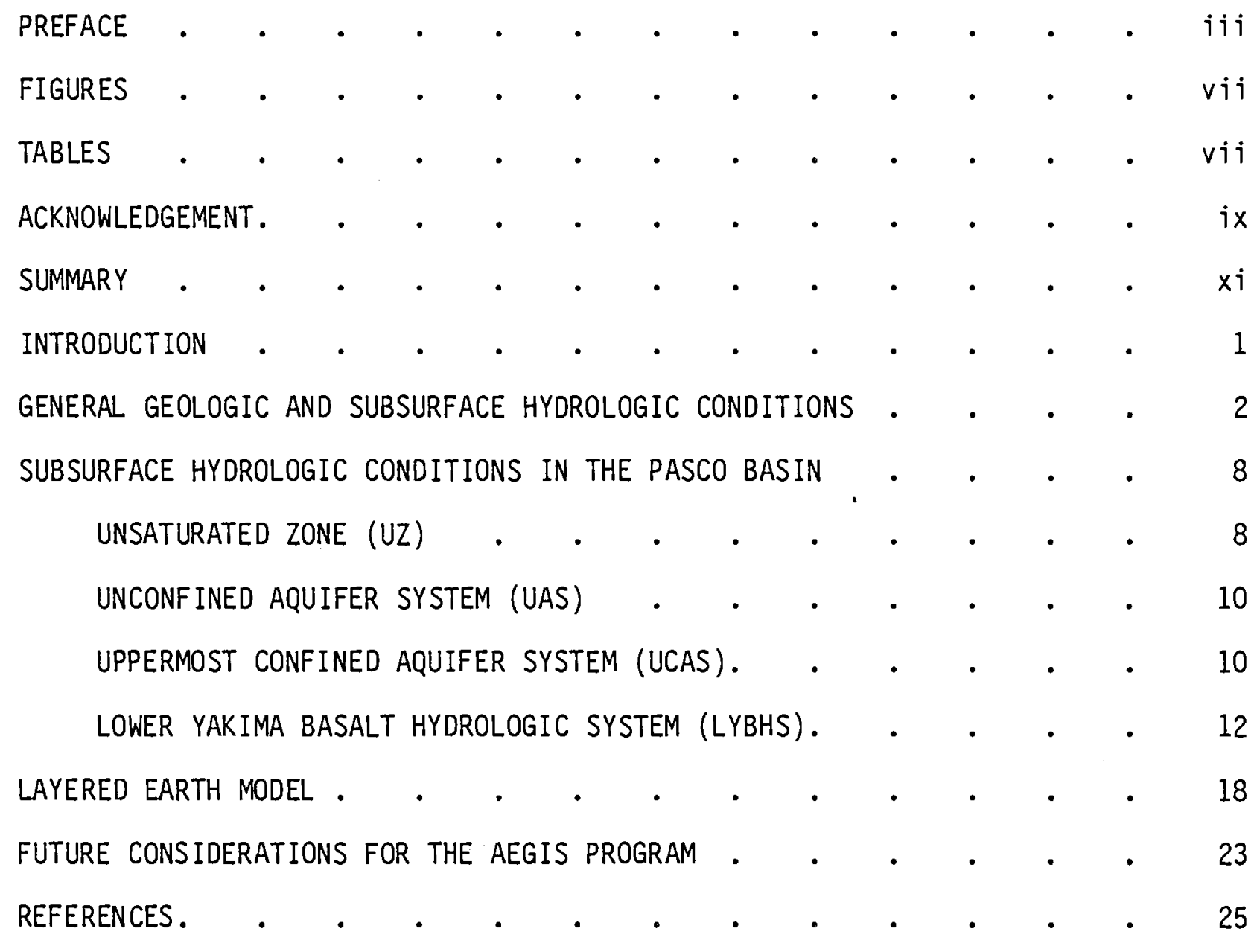




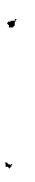




\section{FIGURES}

1 Map Showing the Main Area Underlain by the Columbia River Basalt, Washington, Oregon, and Idaho . . . . 3

2 Schematic Diagram Showing Macrostructure of a Basalt Flow . 5

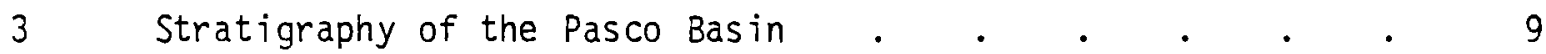

4 Approximate Und isturbed Groundwater Head for Isolated Water-Bearing Zones in We11 ARH-DC-1 (1969) . . . . 13

5 Piezometers Installed in ARH-DC-1 . $5 . \quad . \quad . \quad . \quad . \quad 15$

$6 \quad$ Hydrographs of Depths to Water Below the Lava Surface in Feet and Meters for Piezometers in ARH-DC-1 . . . 16

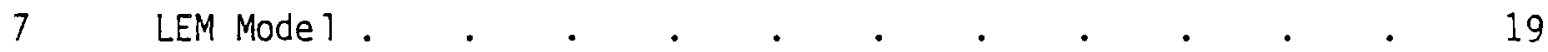

8 Generalized Range of Horizontal Hydraulic Conductivity for Several Rock Types in the Pasco Basin . . . . 20

\section{TABLES}

1 Hydraulic Conductivity of the Unconfined Aquifer

Material . . . . . . . . . . 11

2 Hydraulic Conductivity of the Uppermost Confined Aquifers . 11

3 Range of Hydrologic Properties of Lower Yakima Basalt

Flows and Interbeds . $. \quad . \quad . \quad . \quad . \quad . \quad . \quad . \quad 14$

4 Summary Record of Depths to Water Below the Land Surface in Feet and Meters for Piezometers in ARH-DC-1. . 14 



\section{ACKNOWLEDGMENT}

This research was supported by the Waste Isolation Safety Assessment Program (WISAP) conducted by Pac ific Northwest Laboratory. The program was sponsored by the Office of Nuclear Waste Isolation, managed by Battelle Memorial Institute for the Department of Energy under Contract DE-AC06-76RLO-1830. On 1 October 1979, WISAP became the Assessment of Effectiveness of Geologic Isolation Systems (AEGIS) Program and the Waste/Rock Interactions Technology (WRIT) Program. This report was issued by AEGIS. 


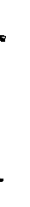




\section{SUMMARY}

This report contains a discussion of the hydrologic conditions of the Columbia River Plateau physiographic province. The Columbia River Plateau is under lain by a thick basalt sequence. The Columbia River basalt sequence contains both basalt flows and sedimentary interbeds. These sedimentary interbeds, which are layers of sedimentary rock between lava flows, are the main aquifer zones in the basalt sequence. Permeable interflow zones, involving the permeable top and/or rubble bottom of a flow, are also water-transmitting zones.

A number of stratigraphic units are present in the Pasco Basin, which is in the central part of the Columbia River Plateau. At a conceptual level, the stratigraphic sequence from the surface downward can be separated into four hydrostratigraphic systems. These are: 1) the unsaturated zone, 2) the unconfined aquifer, 3) the uppermost confined aquifers, and 4) the lower Yakima basalt hydrologic sequence.

The unsaturated zone (UZ) is the zone between the land surface and the water table. Its thickness at the Hanford Site ranges from less than one meter to more than 100 meters. The unsaturated zone consists of silt, sand, and gravel deposits. The moisture content of the unsaturated zone of the Hanford Site is very low.

The unconfined aquifer system (UAS) consists of sand and gravel deposits of glaciofluviatile origin. These deposits rest on the Ringold Formation. The top of the aquifer at any give time is the water table. The base of the aquifer is either the top of the basalt bedrock in some areas or the silt and clay zones of the lower Ringold Formation in other areas. The hydraulic characteristics of the unconfined aquifer system are quite variable.

The uppermost confined aquifer (UCAS) consists of: 1) the sands and gravels of the lower Ringold Formation, 2) the sedimentary interbeds of the upper and middle Yakima basalt sequence, and 3) permeable interflow zones in the top few meters of some flow units. The UCAS is known to be hydraulically 
interconnected at places in the Pasco Basin with the overlying unconfined aquifer, and they appear to be in hydraulic equilibrium.

The lower Yakima basalt hydrologic system (LYBHS) is comprised of the basalt flows and interbeds which underlie the Vantage Sandstone Formation. Very little is known about the direction and movement of groundwater through the lower Yakima basalt sequence and its contained interbeds. However, tests indicate that it contains 2 flow regimes: the upper confined flow regime and the lower confined flow regime.

Hydraulic head relationship between the unconfined aquifer system (UAS), uppermost confined aquifer system (UCAS), and the lower Yakima basalt hydrologic system (LYBHS) are known in a general way. The potentiometric surface of the UCAS ranges from less than one meter to four meters higher than the potentiometric surface of the overlying UAS. For initial modeling purposes, it is recommended that head differences ranging from 1 to 10 meters be considered for these two aquifer sequences. The flow potential should be from the UCAS to UAS. The potentiometric surface of the LYBHS is about two meters higher than the overlying UCAS; therefore, the apparent potential for flow is from the LYBHS to the UCAS. Because the head relationships of these two aquifer systems may be reversed at specific sites, it is recommended, for initial modeling purposes, that head fluctuation ranging from 1 to 10 meters be considered, with comparative runs for flow from the LYBHS to the UCAS and from the UCAS to the LYBHS.

The hydraulic gradient in the UAS ranges from about 0.5 meter to 5 meters per $\mathrm{km}$ throughout the Pasco Basin. The gradient is highest near recharge sources, such as the waste disposal ponds of the 200 West and East Areas of the Hanford Site. The hydraulic gradient in the UCAS is less well known than the UAS. The range in the hydraulic gradient is probably less, in general, than stated above for the UAS; however, it may be greater near the edge of the Pasco Basin (recharge area) and the Columbia River (discharge area). 
Little is known about the hydraulic gradient of the LYBHS. It is probably very low in the central part of the Pasco Basin. For initial modeling simulation runs, a hydraulic gradient range of 0.1 to 1 meter per $\mathrm{km}$ is probably the correct order of magnitude.

A conceptual layered earth model (LEM) has been developed. The LEM represents the major types of porous media (LEM units) that may be encountered at a number of places on the Columbia Plateau, and specifically in the Pasco Basin. The conceptual LEM is not representative of the actual three-dimensional hydrostratigraphic sequence and hydrologic conditions existing at any specific site within the Columbia Plateau physiographic province. However, the LEM may be useful for gaining a better understanding of how the hydrologic regime may change as a result of disruptive events that may interact with a waste repository in geologic media. 



\section{$\underline{\text { INTRODUCTION }}$}

Repository simulation is one safety assessment approach to evaluating a potential release scenario for a nuclear waste repository in geologic media. Development of properly scaled, conceptually valid, repository simulation models are needed if reliable aqueous transport comparisons and conclusions are to be realized. Such models could provide insight on the significance of aqueous transport associated with potential disruptive phenomena interacting with a radioactive waste repository in geologic media. Many of the disruptive phenomena identified by the staff working on the Assessmnet of Effectiveness of Geologic Isolation Systems (AEGIS) program have hydrologic implications that are of local and/or regional hydrologic significance.

Subsurface hydrologic conditions in the Pacific Northwest are strongly controlled by the structural and stratigraphic framework of subregions. The subregions may encompass hundreds of square miles and are, therefore, large in comparison to the underground space required for a waste repository. The aquifer system or systems may be relatively small with in a subregion, compared to the areal extent and volume of geologic media within the subregion. These geologic media can experience a change in state of stress (mechanical and/or hydraulic) due to regional forces. These forces might be imposed by some of the identified disruptive phenomena, such as glaciation, tectonic forces, igneous intrusion and volcanic extrusion.

The subsurface hydrology of the Pacific Northwest is a broad subject. It is briefly discussed below as an introduction to a more site-specific discussion which follows. A significant portion of the Pacific Northwest is underlain by the Columbia River Plateau basalt sequence. If a decision is made to locate a waste repository in the Pacific Northwest, it is reasonable to assume that such a repository may be located in this rock sequence and its associated hydrologic system or systems. Therefore, this discussion is limited to hydrologic conditions as they relate to the Columbia River Plateau physiographic province and specifically to the Pasco Basin in the central part of the province. 


\section{GENERAL GEOLOGIC AND SUBSURFACE HYDROLOGIC CONDITIONS}

The Columbia River Plateau physiographic province is bounded by the Okanogan Highland to the north, the Clearwater Mountains to the east, the Blue Mountains to the south, and the Cascade Range to the west (Figure 1). This region is a broad structural basin. Its topographical and structural low points occur in the Pasco Basin near Pasco, Washington, in the central part of the Columbia Plateau. From the Pasco Basin, the plateau surface rises gently toward the surrounding highlands.

The geologic history of the Columbia Plateau can be traced back about 15 million years. Mckee (1972) suggests that there is obviously a much older story in the rock record beneath the thick basalt sequence. However, geologists can only guess what the pre-Miocene geologic history may be by studying the older rocks that disappear under the basalt flows around the edge of the plateau; no significant windows have been eroded through the Columbia River basalt sequence. The bedrock does not consist entirely of basalt. Between at least some volcanic eruptions, rivers flowed out onto the flood basalt lava plain. They transported and deposited sediments along their course and into shallow lakes. Therefore, layers of sedimentary rock (sedimentary interbeds) occur between lava flows. Furthermore, these interbeds are the main aquifer zones in the basalt sequence of the Pasco Basin.

Strata of Pliocene age overlie the Miocene basalt sequence. The Pliocene strata consist mainly of stream and lake sediments which contain a few interbedded basalt flows. Mckee (1972) states that large scale deformation of the region has occurred during the past ten million years. The Columbia River basalt sequence dips away from the surrounding mountains as a result of uplift of the ranges and sinking of the plateau. Many folds and minor faults have locally warped and, in some instances, broken the basalt flows.

The individual lava flows range in thickness from a few meters to over 50 meters. Mckee (1972) states that the magma eruptions were not from a single vent but from very long fissures, each of which were many miles long. Therefore, an individual eruption was probably fed by many fissures transporting basaltic magma simultaneously. In the central part of the plateau, the 


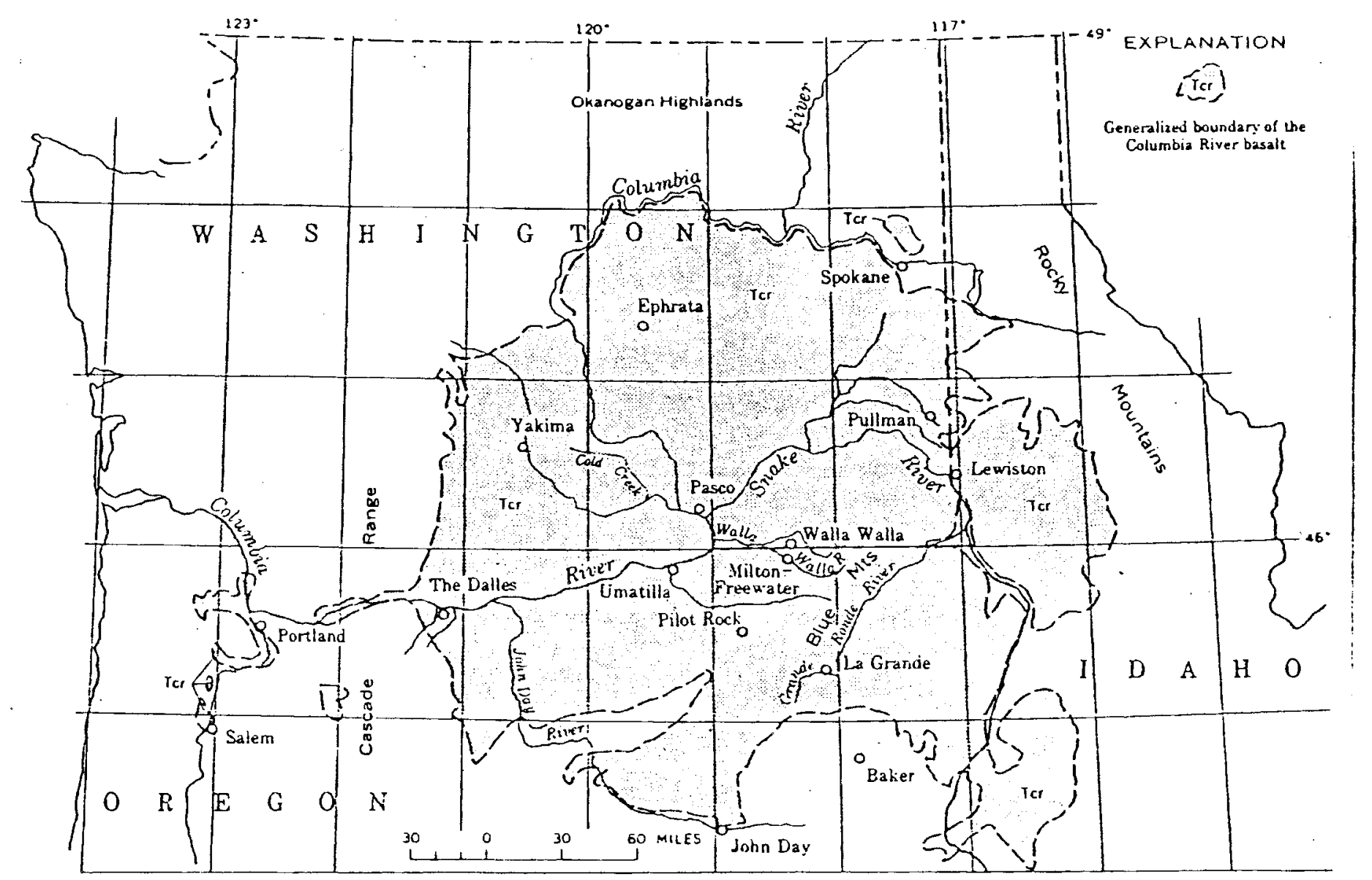

FIGURE 1. Map Showing the Main Area Underlain by the Columbia River Basalt, Washington, Oregon, and Idaho

Source: Newcomb 1961, Figure 1 
basalt is known to be more than 3,000 meters thick (La Sala, 1971, 1973). It thins to a zero edge on older rocks at its margins. Newcomb (1961) states that the flows average about 50 feet in thickness, whereas Mckee (1972) indicates that a "typical" flow is about 100 feet thick. Newcomb characterized an average flow as consisting of "dense, almost flint-like, partly fractured rock at its base; grades vertically to dense, massive columnar-jointed rock at its center; and then to vesicular - and in some places rubbly-rock at the top."

Systems of fractures cut the rock into irregular columnar, cubical, and platy blocks. These fractures and primary structures were formed when the lava was cooling. Mckee (1972) suggests that a typical Columbia River basalt flow may have taken several decades to solidify completely. In each flow the lava crystallized from the bottom upward as we 11 as from the top downward. Crystallization of a flow inward from the bottom and top surfaces may produce two distinct layers. In cliff exposures these two layers have been misinterpreted as two distinct flows. This two-part layering of a flow is shown schematically in Figure 2. The bottom part is known as the colonnade and the top is known as the entablature. These primary structures lead the casual observer to conclude that basalt flows are quite pervious, especially in the vertical plane, when seen at the surface. However, at depth, under the load of overlying rock, fractures are for the most part closed and may transmit little or no groundwater.

Newcomb (1961) has extensively studied the general occurrence and movement of groundwater in the Columbia Plateau. He has concluded that groundwater movement takes place mostly in the permeable zones in the tops of some flows. These permeable zones are about 1 to 3 meters thick. In places, where two permeable interflow zones are separated by a highly-jointed basalt with open joints, the thickness of a single water-bearing zone may be 10 meters or more. One of Newcomb's most pertinent observations is that the massive centers of some basalt flows are relatively impermeable, and in some places zones of rock consisting of several successive flows are tight and non-waterbearing. These impermeable zones can cause perched water bodies to occur above and below the regional water table. They may act as effective confining zones between water-bearing zones of different head. 


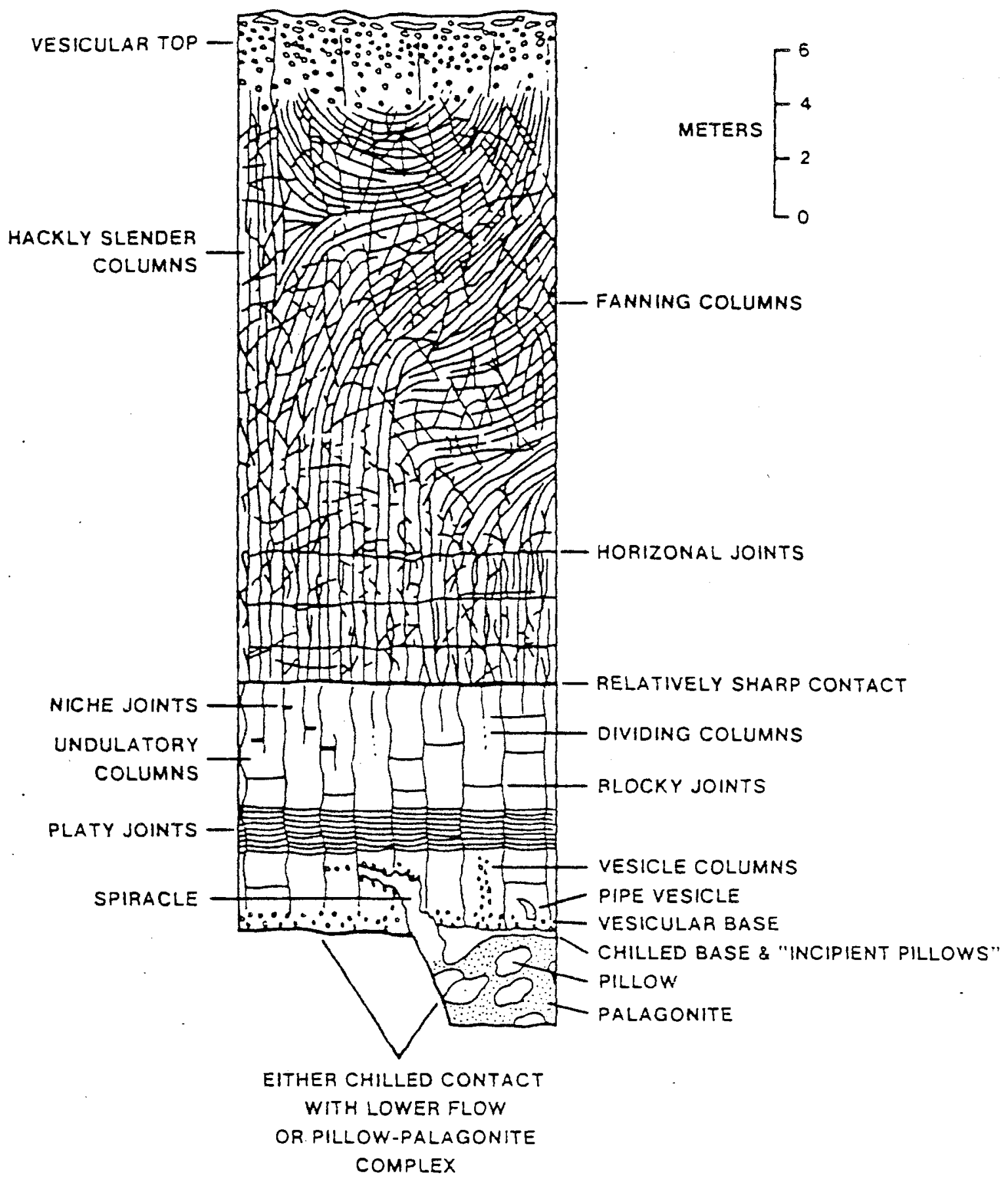

FIGURE 2. Schematic Diagram Showing Macrostructure of a Basalt Flow Source: ARHCO 1976, Figure 5 
Evidence to date suggests that, in genera1, the most permeable watertransmitting zones are sedimentary interbeds or permeable inter-flow zones involving the permeable and/or rubble bottom of a flow. Some of the sedimentary interbeds are the most prolific water-bearing units of areal extent known to occur. These occur at several horizons in the basalt sequence above the lower Yakima Basalt Formation, as defined by Ledgerwood (1976).

Newcomb's (1961) regional observations, in general, suggest that groundwater movement in the Columbia Plateau region is from upwarped anticlinal areas to downwarped synclinal areas. He notes that many of the highly productive wells in the Columbia River basalts occur in synclinal areas, such as those which occur at Walla Walla, Cold Creek, and Ephrata, Washington; the Dalles, Umatilla, and Pilot Rock, Oregon; and Lewiston, Idaho. Another structural control of regional and local significance observed by Newcomb $(1961,1969)$ is the fault-barrier boundary condition. The faults range from large shear fractures along which the rocks on opposite sides were displaced several thousand feet to small ones on which little displacement has occurred.

The large faults exist as zones of shattered and broken rock several tens or even hundreds of meters wide rather than as single planes. Smaller faults with displacements of a few meters are zones of sheared and shattered rock, according to Newcomb (1961). Most of the faults are of the normal displacement type.

The water-transmitting characteristics of the fault zones differ markedly from those of unbroken basalt. Fault fracturing may provide a zone of low permeability through which small quantities of water can move vertically. This vertical movement may be either up or down, depending on local head conditions. Permeable interflow zones and sedimentary interbeds, where present, transmit water laterally in a horizontal to sub-horizontal direction. Newcomb (1961) has shown in a number of instances that horizontal movement has been virtually eliminated by the fault zones. Thus, a fault zone may act as a barrier to otherwise normal lateral movement of groundwater from points of higher to lower head in the Columbia River basalt sequence. Barriers to lateral movement of groundwater can also occur along the axes of tight folds due to 
the disruption of permeable zones by the interflow grinding that accompanies bedding plane movement of one flow over another.

Intrusive dikes can also form barriers to lateral ground-water movement. Dikes are not as numerous as the structural barriers discussed above. However, they are known to occur. They are most effective as barriers when they occur transverse to the direction of lateral ground-water movement. 
The detailed hydrogeology of the Columbia Plateau is not we 11 known. General hydrologic information below a depth of 500 meters in the basalt sequence is lacking throughout the Plateau except for the U.S. Department of Energy's (DOE) Hanford Site in the Pasco Basin. The information gained from hydrologic testing on and adjacent to the Hanford Site is discussed briefly below. The purposes of the discussion are: 1) to establish a conceptual layered earth model (LEM) for the types of strata present in the Pasco Basin to a depth of about 1,000 meters, and 2) to set some limits and ranges on the permeabilities and head differences that may be applicable for a generic transport modeling scheme of the LEM.

The stratigraphy of the Pasco Basin is summarized in Figure 3. A number of stratigraphic units are present. At a conceptual leve1, the stratigraphic sequence from the surface downward can be separated into four hydrostratigraphic systems. They are 1) the unsaturated zone, 2) the unconfined aquifer, 3) the uppermost confined aquifers, and 4) the lower Yakima basalt hydrologic sequence.

UNSATURATED ZONE (UZ)

The unsaturated zone (UZ) is the zone between the land surface and the water table. Perched water bodies may exist within the unsaturated zone. Its thickness at the Hanford Site ranges from less than one meter to more than 100 meters (ARHCO, 1976). The unsaturated zone consists of silt and sand deposits of eolian origin and sand and gravel deposits of glaciofluviatile origin. The moisture content of the unsaturated zone of the Hanford site is very low. Any transport modeling coupling the unsaturated zone with the saturated zone should simulate two-phase fluid flow to analyze any waste release scenarios that involve the unsaturated zone. 


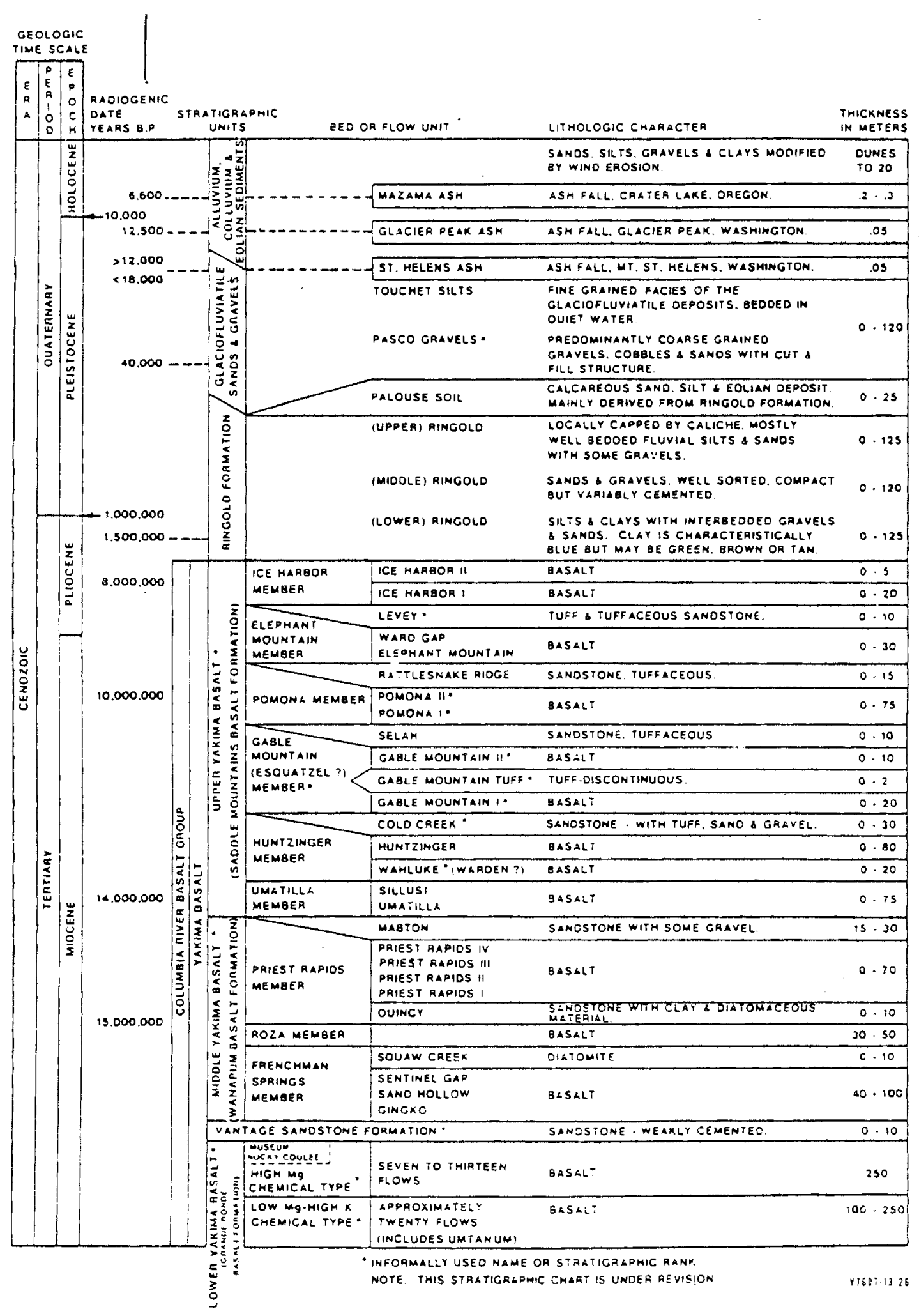

FIGURE 3. Stratigraphy of the Pasco Basin

Source: ARHCO 1976, Figure 6 
UNCONFINED AQUIFER SYSTEM (UAS)

The unconfined aquifer system (UAS) consists of sand and gravel deposits (Pasco Gravels) of glaciofluviatile origin. These deposits rest unconformably on an interbedded sequence of fluvial silts, sands, and some gravels (upper Ringold Formation) which are locally capped by caliche. These deposits are under lain by variably cemented sand and gravel units (middle Ringold Formation). The top of the aquifer at any given time is the water table. The base of the aquifer may be either the top of the basalt bedrock or the silt and clay zones of the lower Ringold Formation. In places, glaciofluviatile gravel may lie directly on basalt. In such cases, the top of the unconfined aquifer may be in the glaciofluviatile gravel.

The hydraulic characteristics of the unconfined aquifer system are quite variable. This variability is a result of the heterogeneous nature of the aquifer materials in three-dimensional space. The range in the hydraulic conductivity of the unconfined aquifers is summarized in Table 1. Very large hydraulic conductivity values are only representative for the open lattice work gravel strata of the glaciofluviatile deposits.

Natural recharge of the aquifer occurs at the foot of Rattlesnake Hills and Yakima Ridge and by vertical leakage from the underlying uppermost confined aquifer system. Artificial recharge occurs from waste disposal ponds on the Hanford Site. The Yakima River recharges the unconfined aquifer along its reach from Horn Rapids to Richland (ARHCO, 1976). Natural discharge from the aquifer occurs along the Columbia River.

\section{UPPERMOST CONFINED AQUIFER SYSTEM (UCAS)}

The uppermost confined aquifer (UCAS) consists of: 1) the sands and gravels of the lower Ringold Formation; 2) the sedimentary interbeds of the upper and middle Yakima basalt sequence; and 3) permeable interflow zones in the top few meters of some flow units. Seven sedimentary interbeds are known to exist in the upper and midd le Yakima basalt sequence in the Pasco Basin (Figure 3). The range in the hydraulic conductivity of the UCAS is summarized in Table 2. 
TABLE 1. Hydraulic Conductivity of the Unconfined Aquifer Material

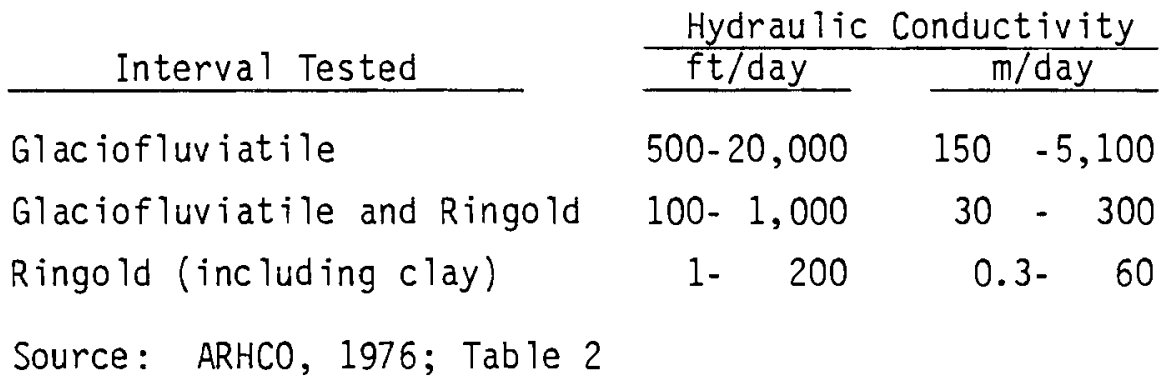

TABLE 2. Hydraulic Conductivity of the Uppermost Confined Aquifers

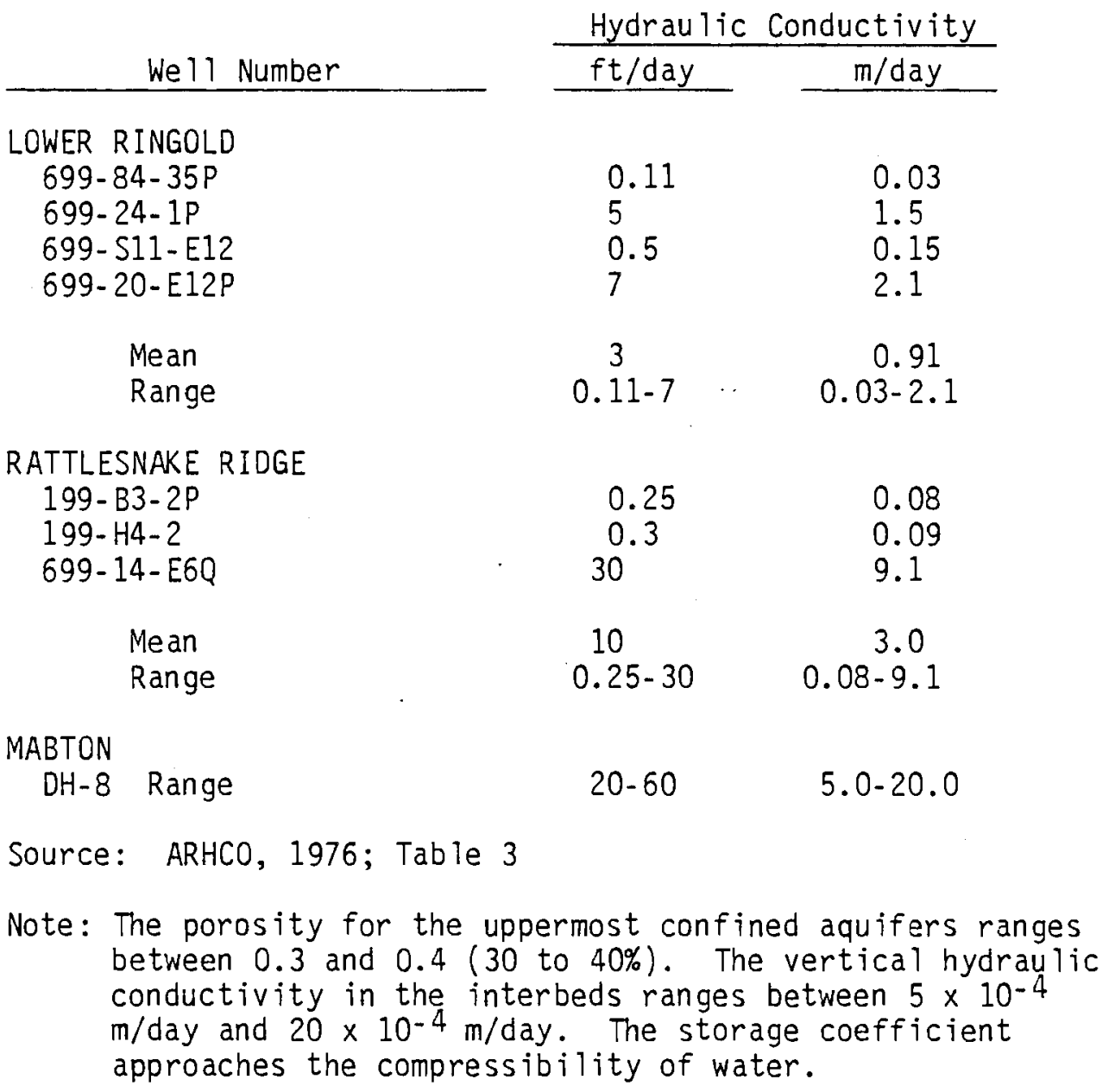


The UCAS is known to be hydraulically interconnected at places in the Pasco Basin with the over lying unconfined aquifer. This interconnection occurs where the basalt units have been extensively deformed by folding and differential erosion, such as along major anticlinal axes. Near such folded areas, the basalt flows dip steeply away from the axial plane of the anticline. The ancestral Columbia River deeply eroded away portions of the unconfined aquifer and steeply dipping segments of the uppermost confined aquifer units prior to the deposition of younger strata. Therefore, the hydrologic data collected to date suggest that the unconfined aquifer and the the uppermost confined aquifer appear to be in hydraulic equilibrium (ARHCO 1976). Recharge to the UCAS appears to occur at the ridges and plateaus fringing the Pasco Basin. The eastern third of the Hanford Site appears to be a discharge area for this aquifer system.

\section{LOWER YAKIMA BASALT HYDROLOGIC SYSTEM (LYBHS)}

The hydrology of the lower Yakima Basalt sequence is of utmost importance in assessing the hydrologic suitability of a localized, permanent wasteisolation repository in geologic media of the Pasco Basin. The Vantage Sandstone Formation of Figure 3 is the lowermost sedimentary interbed of areal extent known to exist in the Pasco Basin. It separates the Tower Yakima Basalt sequence from the overlying middle Yakima Basalt sequence. Approximately 300 meters below the Vantage Sandstone horizon is a basalt interval ("Umtanum") of special interest. Cores and geophysical logs on this interval suggest that it is a very tight, dense, glassy basalt flow that is about 60 meters thick.

Direct measurements of head were first obtained in 1969, in discrete water-bearing zones in We 11 ARH-DC-1 on the Hanford Reservation (ARHCO 1976). These measurements are summarized in Figure 4. They show that the intervals tested in the lower Yakima Basalt sequence from a depth of about 915 to 1310 meters tend to either have the same head as intervals tested above the "Umtanum" flow unit (dept'h of 915 meters) or slightly lower heads. 


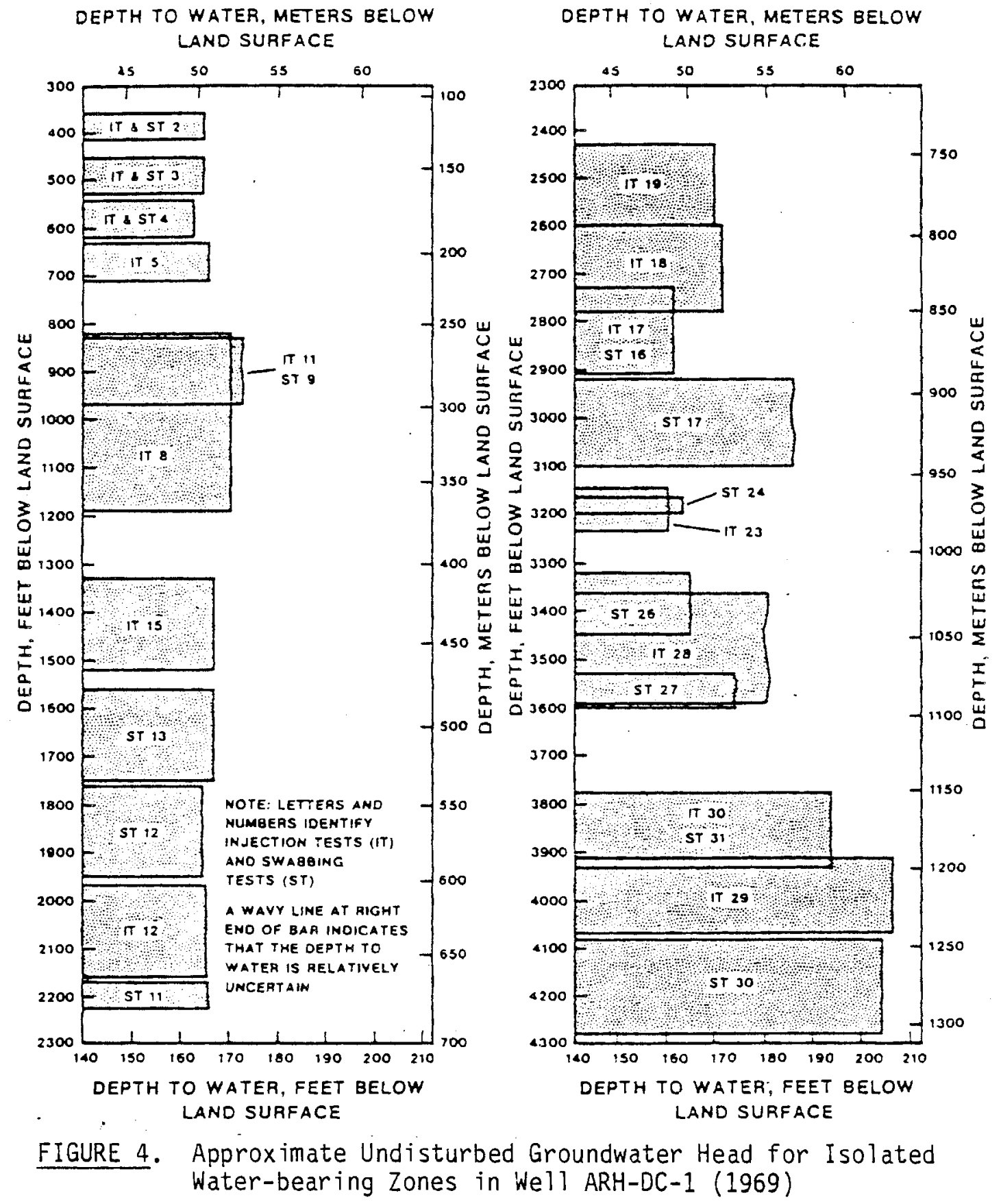

Source ARHCO 1976, Figure 10 
TABLE 3. Range of Hydrologic Properties of Lower Yakima Basalt Flows and Interbeds

\section{Dense basalt \\ Vesicular basalt}

Fractured, weathered or brecciated basalt

Interbed

\begin{tabular}{|c|c|}
\hline \multicolumn{2}{|c|}{ Hydraulic Conductivity } \\
\hline $\mathrm{ft} / \mathrm{day}$ & $m /$ day \\
\hline $1 \times 10^{5}-3 \times 10^{3}$ & $3 \times 10^{-6.9 \times 10^{-4}}$ \\
\hline $1 \times 10^{-3} .1 \times 10^{-2}$ & $3 \times 10^{-4} .3 \times 10^{-3}$ \\
\hline
\end{tabular}

$3 \times 10^{-3.5}$

$3 \times 10-3.10$

$3 \times 10^{-4} \cdot 1.5$

$9 \times 10^{-4}-3$

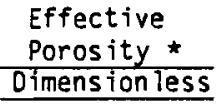

$0.1-1$

5

10

20
Storage Coefficient Dimension less

$1 \times 10^{-5.1 \times 10^{-6}}$

$1 \times 10^{-4}$
$1 \times 10^{-3}$

$1 \times 10^{-2}$

‡ Volume percent

Source: ARHCO 1976, Table 5

TABLE 4. Summary Record of Depths to Water Below the Land Surface in Feet and Meters for Piezometers in ARG-DC-1

\begin{tabular}{|c|c|c|c|c|c|c|c|c|c|c|}
\hline \multirow{3}{*}{$\begin{array}{c}\text { Measurement } \\
\text { Date }\end{array}$} & \multicolumn{10}{|c|}{ Piezoneter Tube } \\
\hline & \multicolumn{2}{|c|}{$\mathrm{I}$} & \multicolumn{2}{|c|}{$\overline{2}$} & \multicolumn{2}{|c|}{3} & \multicolumn{2}{|c|}{4} & \multicolumn{2}{|c|}{5} \\
\hline & $\mathrm{ft}$ & $m$ & $\mathrm{ft}$ & $\mathrm{m}$ & $\mathrm{ft}$ & $\mathbf{m}$ & $\mathrm{ft}$ & $\mathrm{m}$ & $\mathrm{ft}$ & $\mathrm{m}$ \\
\hline $06 / 09 / 72$ & 157.33 & 49.95 & 158.03 & 48.16 & 158.39 & 48.28 & 141.37 & 43.09 & 163.00 & 49.68 \\
\hline $07 / 06 / 72$ & 157.05 & 47.87 & 157.71 & 48.07 & 158.10 & 48.19 & 142.33 & 43.38 & 162.82 & 49.63 \\
\hline $07 / 13 / 72$ & 157.02 & 47.86 & 157.63 & 48.05 & 158.00 & 48.16 & 143.40 & 43.71 & 162.94 & 49.66 \\
\hline $07 / 20 / 72$ & 156.91 & 47.83 & 157.50 & 48.01 & 157.90 & 48.13 & 144.24 & 43.96 & 163.00 & 49.68 \\
\hline $08 / 10 / 72$ & 157.07 & 47.87 & 158.00 & 48.16 & 158.38 & 48.27 & 146.42 & 44.63 & 162.78 & 49.62 \\
\hline $08 / 17 / 72$ & 157.34 & 47.96 & 158.21 & 48.22 & 158.58 & 48.34 & 147.18 & 44.86 & 162.88 & 49.65 \\
\hline $08 / 24 / 72$ & 157.27 & 47.94 & 158.00 & 48.16 & 158.42 & 48.29 & 148.28 & 45.20 & 162.30 & 49.47 \\
\hline $08 / 30 / 72$ & 157.45 & 47.99 & 158.17 & 48.21 & 158.52 & 48.32 & 148.28 & 45.20 & 162.30 & 49.47 \\
\hline $09 / 07 / 72$ & 157.25 & 47.93 & 157.88 & 48.12 & 158.26 & 48.24 & 148.81 & 45.36 & 162.81 & 49.62 \\
\hline $09 / 21 / 72$ & 156.97 & 47.84 & 157.57 & 48.03 & 157.94 & 48.14 & 149.69 & 45.63 & 162.83 & 49.63 \\
\hline $09 / 28 / 72$ & 157.52 & 48.01 & 157.75 & 48.08 & 158.07 & 48.18 & 150.29 & 45.81 & 163.06 & 49.70 \\
\hline $10 / 05 / 72$ & 157.36 & 47.96 & 157.88 & 48.12 & 158.25 & 48.23 & 150.80 & 45.96 & 163.22 & 49.75 \\
\hline $12 / 30 / 74$ & & 47.47 & & 47.63 & 156.67 & 47.75 & 158.90 & 48.43 & 162.56 & 49.55 \\
\hline $04 / 18 / 75$ & 155.28 & 47.33 & 155.60 & 47.43 & 156.35 & 47.66 & 163.70 & 49.90 & 162.24 & 49.45 \\
\hline $09 / 03 / 75$ & 155.39 & 47.36 & 155.69 & 47.45 & 156.44 & 47.68 & 164.08 & 50.01 & 162.30 & 50.69 \\
\hline $12 / 16 / 75$ & 155. & 47.42 & 155.47 & 47.39 & 156.50 & 47.70 & 164.96 & 50.28 & 163.37 & 49.80 \\
\hline
\end{tabular}

Source: ARHCO 1976, Table 6 


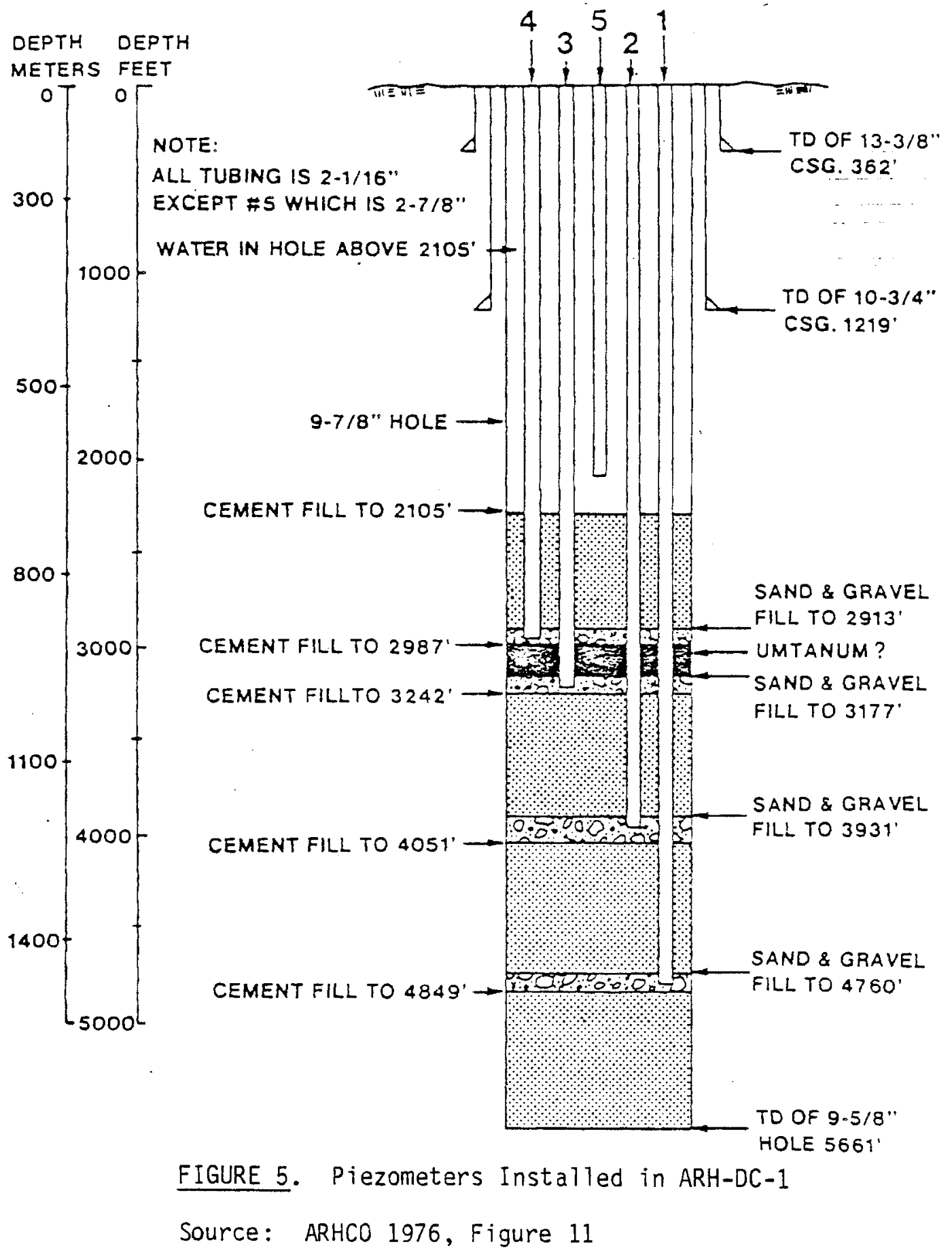




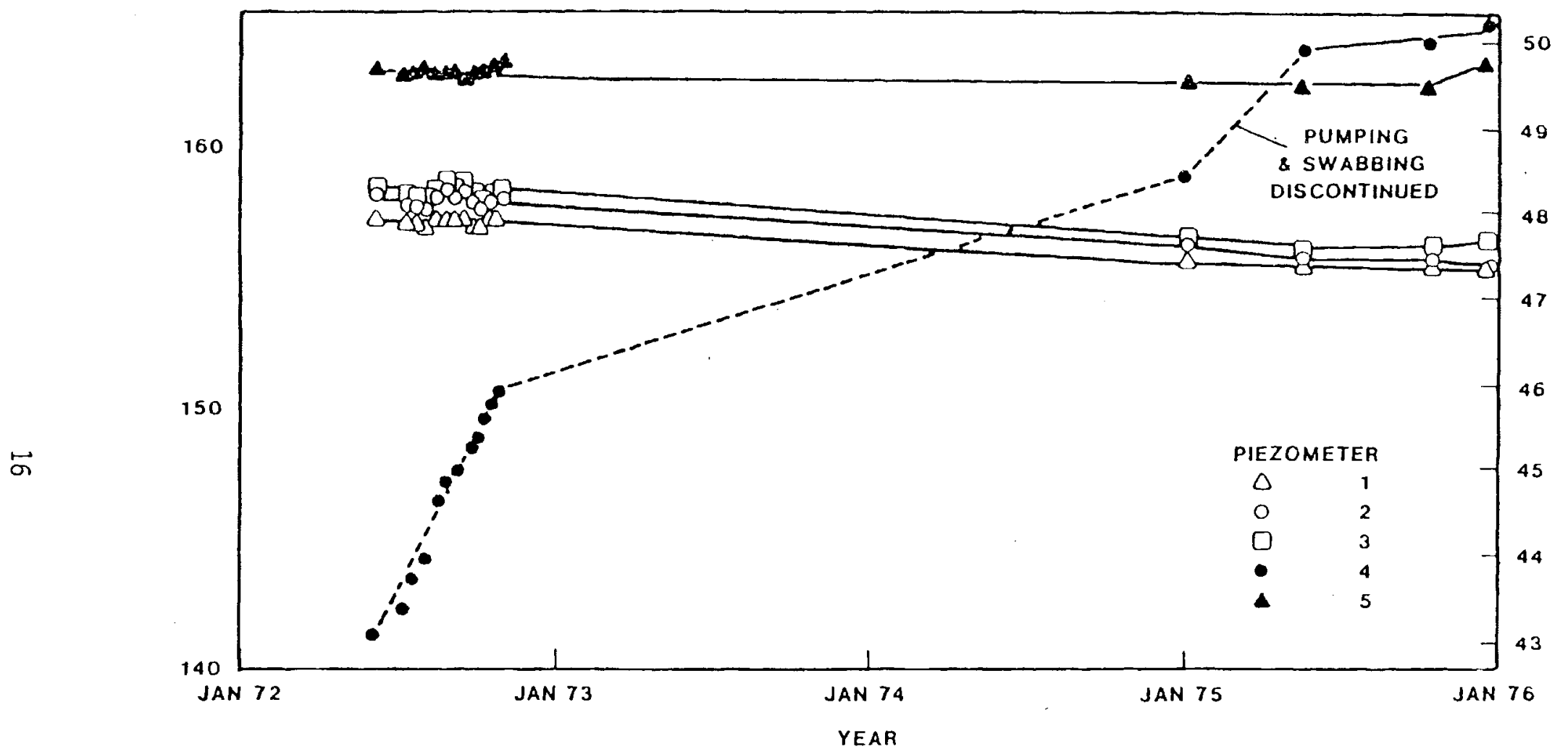

FIGURE 6. Hydrographs of Depths to Water Below the Lava Surface in Feet and Meters for Piezometers in ARH-DC-1

Source: ARHCO 1976, Figure 12 
Swabbing and injection tests were conducted by the USGS in We 11 ARH-DC-1 to determine the transmissivity and storage coefficient of selected intervals downhole (ARHCO 1976). Laboratory analyses on five core samples from the lower Yakima Basalt sequence were obtained. The results of the injection tests are given in Table 3. These data combined with lithologic data allow definition of the hydraulic characteristics of the four principal lithologic types found in the lower Yakima Basalt sequence of the Pasco Basin.

In 1972, five isolated piezometers (Figures 5 and 6) were installed in We 11 ARH-DC-1. Water-level measurements in these piezometers are summarized in Figure 6 and Table 4 . These results suggest that a potential hydraulic interconnection of the basalt and interbeds probably exists above a depth of 915 meters (upper confined flow regime). The flow regimes below 970 meters appear to be connected down to a depth of at least 1480 meters (lower confined flow regime). The "Umtanum" flow unit separates these two hydraulic flow regimes. It would appear that the difference in head between the upper and lower flow regimes is presently about 2 meters, with the potential flow direction being apparently from the lower confined to the upper confined flow regime.

Very little is known about the direction and movement of groundwater through the lower Yakima basalt sequence and its contained interbeds. However, ground-water movement in these deep rock sequences should be influenced by primary and secondary basalt flow solidification structures and tectonic structures, chiefly fractures (joints and faults). Newcomb (1961) has shown that faults can be very effective ground-water flow barriers of regional significance within the Columbia River Plateau physiographic province. 


\section{LAYERED EARTH MODEL}

The conceptual layered earth model (LEM) represents the major types of porous media (LEM units) that may be encountered at a number of places on the Columbia Plateau, and specifically in the Pasco Basin. The purpose of the LEM is to provide a basis for gauging the effect that disruptive event phenomena of a geologic nature might have on a radioactive waste repository in geologic media of the Columbia Plateau physiographic province. The conceptual LEM is not representative of the actual three-dimensional hydrostratigraphic sequence and hydrologic conditions existing at any specific site within the columbia Plateau physiographic province. However, the LEM may be useful for gaining a better understanding of how the hydrologic regime, and specifically transport rates, may change as a result of disruptive events that may interact with a waste repository in geologic media.

A conceptual LEM is presented on Figure 7, and Figure 8 summarizes the estimated range in horizontal hydraulic conductivity for various LEM units. The mode 1 consists of 18 layers. It does not represent the minimum or maximum number of layers that might be involved in a Columbia Plateau repository site. However, it shows the degree of complexity that is known to exist in the vertical plane.

The estimated range in the hydraulic conductivity of each LEM un it is based on cursory field data acquired at the Hanford Site (ARHCO 1976).

The range in the vertical hydraulic conductivity of the various LEM units is not we 11 known. However, it appears reasonable to assume that the vertical hydraulic conductivity of a specific LEM unit is at least one order of magnitude and possibly two orders of magnitude less than the horizontal hydraulic conductivity. This conclusion is probably not applicable to some of the thinner basalt flows that have a well developed colonnade section; i.e., the vertical permeability may be considerably higher than the horizontal permeability where the depth of burial is relatively shallow. 


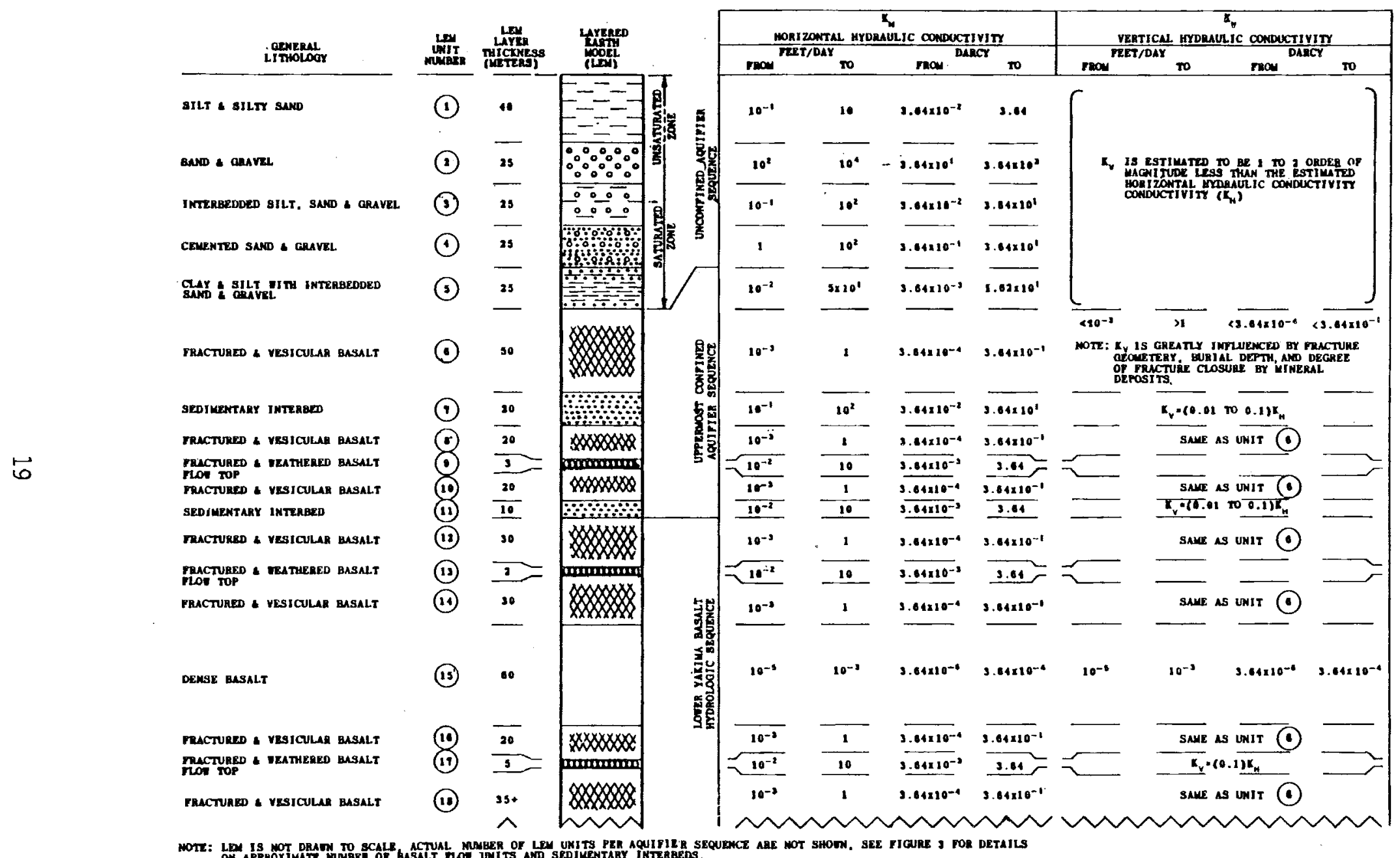

FIGURE 7. LEM Mode $]$ 


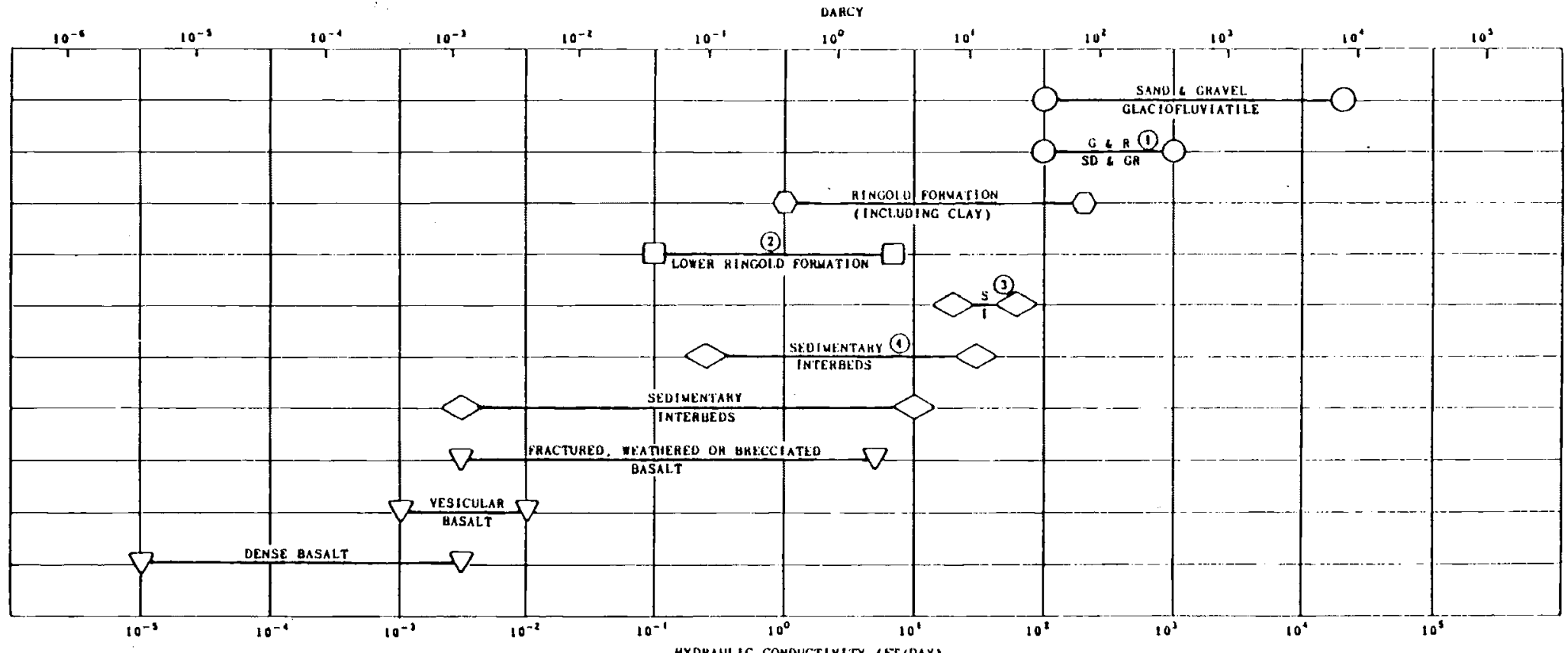

SOUHCE: ARN-ST-13?

motes:

1. Gea (Pasco gavels and hingold gravels)

2. MAIMLY CLAY ANO SILT "ITH INTEREEDoEd Sand \& GRAVEL

3. MABTON SEOIMENTARY INTERBED

4. RATTLESAake MIDGE SEDIMENTARY INTERBEd

FIGURE 8. Generalized Range of Horizontal Hydraulic Conductivity for Several Rock Types in Pasco Basin

Source: ARHCO 1976 
Some of the basalt flows are highly jointed. Field and rock core evidence, however, suggest that some of these flows may be impervious to water. Inspection of basalt joints and fractures show that secondary minerals, predominantly clays such as beidellite and nontronite, fill the joints and other fractures, effectively sealing them (ARHCO 1976). Newcomb (1961) has observed at other places on the Columbia Plateau that "the massive centers of some flows are relatively impermeable, and in places thick zones of the rock consist of several successive flows which are tight and non-waterbearing. "He also observed that "above the water table, these impermeable zones cause water to be perched, and below that level, in places, they cause the water-bearing zones to have no hydraulic continuity and, therefore, to have different waterpressure leve 1s."

Hydraulic head relationships between the unconfined aquifer system (UAS), uppermost confined aquifer system (UCAS), and the lower Yakima Basalt hydrologic system (LYBHS) are known in a general way. The potentiometric surface of the UCAS ranges from less than 1 meter to about 4 meters higher than the potentiometric surface of the overlying UAS (ARHCO 1976). For in itial modeling purposes, it is recommended that head differences ranging from 1 to 10 meters be considered for these two aquifer sequences. The flow potential should be from the UCAS to the UAS. The potentiometric surface of the LYBHS is about 2 meters higher than in the overlying UCAS. Therefore, the apparent potential for flow is from the LYBHS to the UCAS. Because the head relationships of these two aquifer systems may be reversed at specific sites, it is recommended for initial modeling purposes that head fluctuation ranging from 1 to 10 meters be considered, with comparative runs for flow from the LYBHS to the UCAS and from UCAS to the LYBHS.

The above outlined head relationships and estimated ranges in head are based on preliminary data reported for the Hanford Site (ARHCO 1976). The actual head relationships existing at other sites or in other regions of the Columbia Plateau may be considerably different than suggested for the Pasco Basin. 
The hydraulic gradient in the UAS ranges from about 1 meter to 10 meters per mile throughout the Pasco Basin. This gradient is highest near recharge sources, such as the waste disposal ponds of the 200 West and East area of the Hanford Site. A more in-depth discussion of the flow regime in the UAS is given by Newcomb et a 1. (1972). The hydraulic gradient in the UCAS is less we 11 known than for the UAS. The range in the hydraulic gradient is probably less, in general, than stated above for the UAS; however, it may be greater near the edge of the Pasco Basin (recharge area) and the Columbia River (discharge area).

Little is known about the hydraulic gradient of the LYBHS. It is probably very low in the central part of the Pasco Basin. For initial modeling simulation runs, a hydraulic gradient range of 0.1 to 1 meter per mile is probably the correct order of magnitude. 


\section{FUTURE CONSIDERATIONS FOR THE AEGIS PROGRAM}

An initial objective of the AEGIS program was to develop a basalt repository simulation LEM which could be applied to different sites on the Columbia Plateau physiographic province. Careful thought should be given to developing site-specific LEMs. Potential sites on the Hanford Site may require sitespecific Pasco Basin LEMs. A valid comparison of the simulated results between these site-specific LEMs may be possible. However, a valid comparison of these site-specific LEM results for the Pasco Basin with some other structural basin with in the Columbia Plateau may not be possible, using the idealized generic model approach that has been pursued thus far.

Most ground-water flow transport models in use are two-dimensional, and they treat the porous media (LEM units) as isotropic, homogeneous bodies with respect to their hydraulic characteristics. The anisotropic permeability distribution of most of the LEM units necessitates that further consideration be given to developing three-dimensional, anisotropic site-specific transport mode 1s.

Continued research should focus on: 1) selecting the best possible transport model current technology can provide; 2) applying the model to sitespecific LEMs for providing preliminary comparisons; and 3) support of basic research directed towards the aqueous transport of radionuclides in anisotropic, heterogeneous media (specifical1y, the Columbia River basalt sequence). Recently, Streltsova-Adams (1978) discussed the problems associated with well hydraulics in heterogeneous aquifer formations, namely fractured media. 

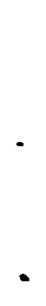


\section{REFERENCES}

ARHCO. 1976. Vol. 1 of Preliminary Feasibility Study on Storage of Radioactive Wastes in Columbia River Basalts. U.S. ERDA Report ARH-ST-137, At lantic Richfield Hanford Co., Richland, WA.

LaSala, A. M., et a1. 1971. Preliminary Evaluation of Hydrologic Factors Related to Radioactive Waste Storage in Basaltic Rocks at the Hanford Reservation, Washington. U.S. Geologic Survey Open-File Report.

LaSala, A. M., et a1. 1973. A Preliminary Evaluation of Regional Ground-water Flow in South-central Washington. U.S. Geological Survey Open-File Report.

Ledgerwood, R. K., and R. A. Deju. 1976. Hydrogeology of the Uppermost Confined Aquifers Underlying the Hanford Reservation. U.S. ERDA Report ARH-SA-253, At lantic Richfield Hanford Co., Richland, WA.

McKee, B. 1972. Cascadia - The Geologic Evolution of the Pacific Northwest. McGraw-Hi11 Book Company, New York, NY.

Newcomb, R. C. 1961. Storage of Ground Water Behind Subsurface Dams in the Columbia River Basalt, Washington, Oregon, and Idaho. U.S. Geological Survey Professional Paper 383-A.

Newcomb, R. C. 1969. Effect of Tectonic Structure on the Occurrence of Ground Water in the Basalt of the Columbia River Group of The Dalles Area, Oregon and Washington. U.S. Geologic Survey Professional Paper 383-C.

Newcomb, R. C., J. R. Strand, and F. J. Frank. 1972. Geology and Ground-water Characteristics of the Hanford Reservation. U.S. Geological Survey Professiona 1 Paper 717.

Stre 1tsova-Adams, T. D. 1978. "We 11 Hydraulics in Heterogeneous Aquifer Formations." In Advances in Hydroscience, ed. V.T. Chow, Vo 1. 11, Academic Press, New York, NY. 


\section{DISTR IBUTION LIST}

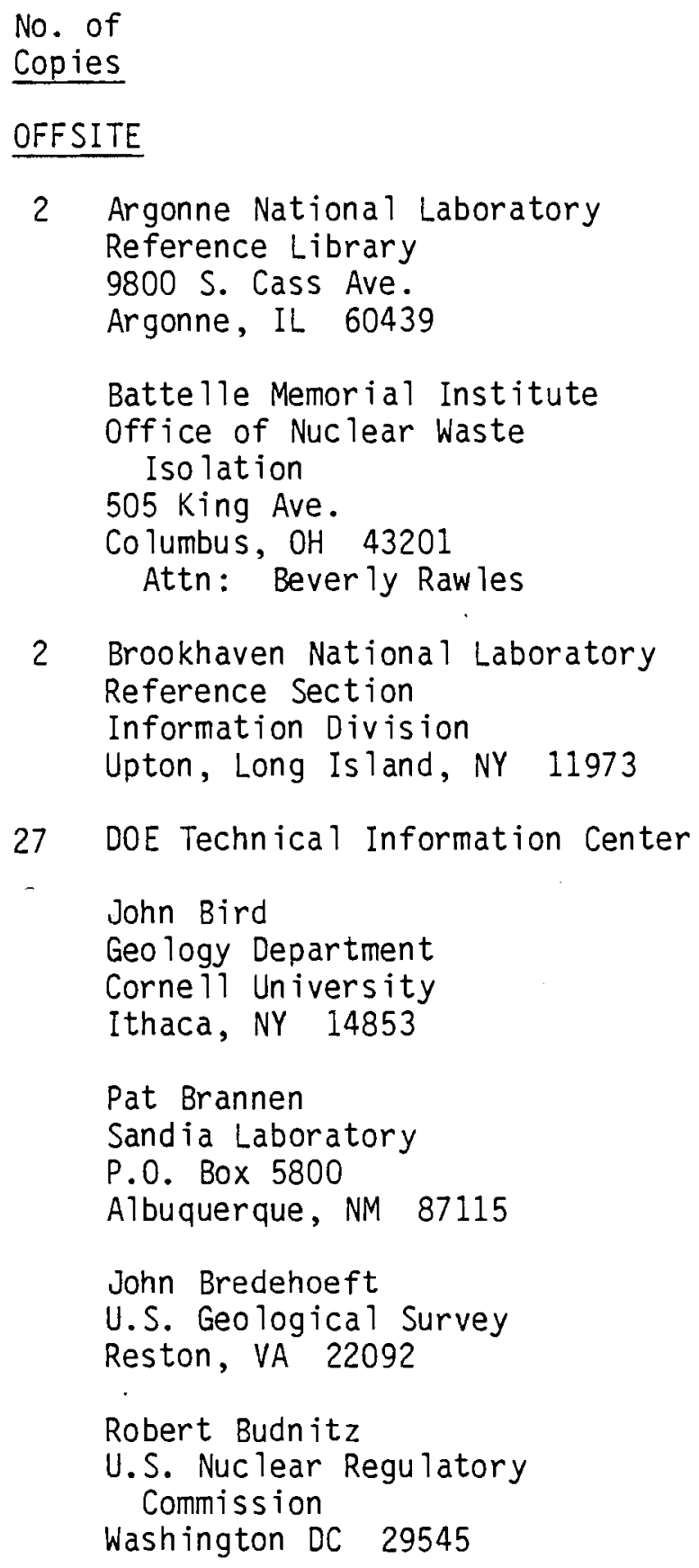

No. of

Copies

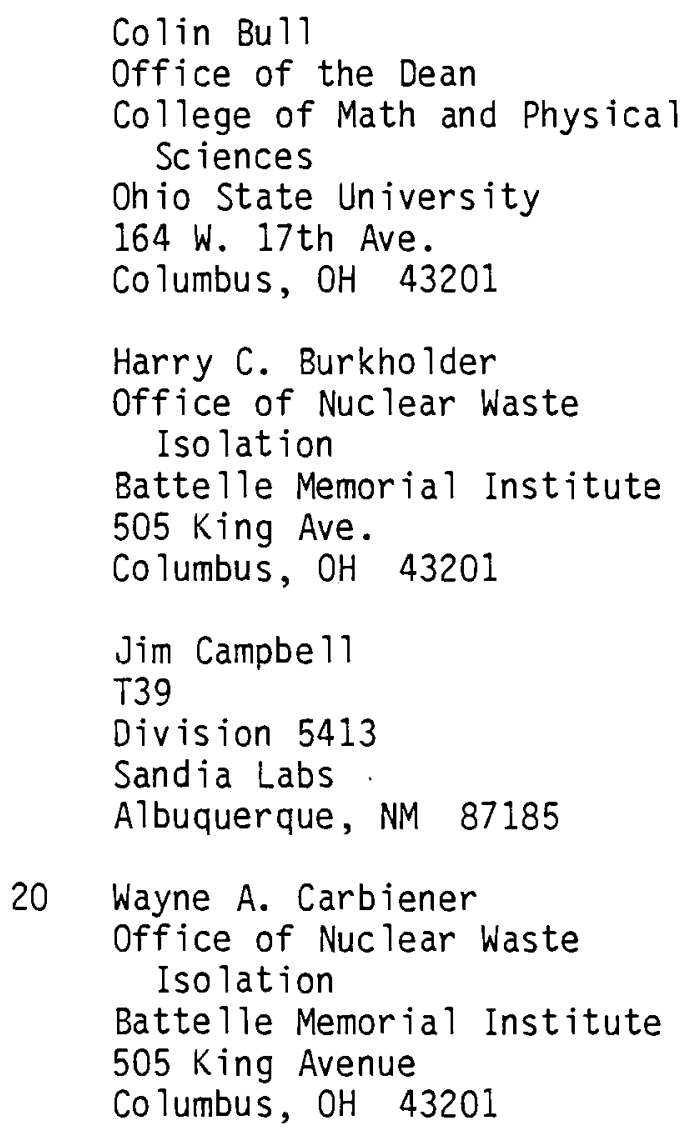

A. A. Churm DOE Patent Division 9800 So. Cass Ave. Argonne, IL 60439

H. Clyde Claiborne Oak Ridge National Laboratory P.0. Box X, Building 3017 Oak Ridge, TN 37830 
No. of

Copies

James Clark

c/o Eugene Vetter

Route 2, Box 70

Shawano, WI 54166

Neville G. W. Cook

Dept. of Materials Science and

Minera 1 Engineering

Hearst Mining Building

University of California

Berke ley

Berkeley, CA 94720

Car 1 R. Cooley

DOE Office of Waste Management

Washington DC 20545

Howard A. Coombs

Department of Geological Sciences

University of Washington

Seattle, WA 98194

James W. Crosby II I

1467 Alpowa

Moscow, ID 83843

Bruce Crowe

Geo logica 1 Research Group, G-6

Los Alamos Scientific Laboratory

P.0. Box 1663

Los Alamos, NM 87545

Jared Davis

27 Nuclear Regulatory Commission Washington DC 20555

Stan ley N. Davis

810 N. Camino Santiago, \#20

Tucson, AZ 85705

G. L. DeBuchananne

U.S. Geological Survey

Reston, VA 22092
No. of

Copies

Terry Donich

Lawrence Livermore Laboratory

P.0. Box 808

Livermore, CA 94550

James Duguid

Office of Nuclear Waste Iso lation

Battelle Memorial Institute

Columbus, $\mathrm{OH} 43201$

Don Easterbrook Western Washington University

Bellingham, WA 98225

Dan Egan

U.S. Environmental Protection Agency

Washington DC 20545

Environmental Protection Agency

Office of Radiation Programs

Technical Assessment Division Aw559

Washington DC 20460

J. G. Feinste in

NUS Corporation

4 Research Place

Rockville, MD 20850

Graham E. Fogg

Bureau of Economic Geology

The University of Texas Aust in

University Station, Box $X$

Austin, TX 78712

Robert M. Garre 11s

Dept. of Geologic Sciences

Northwestern University

Evanston, IL 60201 
No. of

Copies

Raymond D. Gastil

Freedom House

20 W. 40th St.

New York, NY 10018

Earnest Gloyna

National Academy of Sciences

University of Texas

Austin, TX 78712

George Griswold

Tecolote Corporation

531 Wagon Train Drive SE

A1buquerque, NM 87123

Char les R. Had lock

Arthur D. Little, Inc.

Acorn Park

Cambridge, MA 02140

Colin A. Heath

DOE Division of Waste Management

Washington DC 20545

William M. Hewitt

Office of Nuclear Waste Iso lation

Batte lle Memorial Institute

505 King Ave.

Columbus, $\mathrm{OH} 43201$

John M. Hills

818 Kerbey Ave.

El Paso, TX 79902

Peter L. Hofmann

Office of Nuclear Waste Iso lation

Batte lle Memorial Institute

505 King Avenue

Columbus, $\mathrm{OH} 43201$
No. of

Copies

John T. Holloway

Committee on Radioactive Waste

Management $\mathrm{JH}-826$

Nationa 1 Academy of Sciences

2101 Constitution Ave. NW

Washington DC 20418

Vojin Joksimovic

General Atomic Company

P.0. Box 81608

San Diego, CA 92138

Lou is S. Karably

Law Engineering

2749 De lk Road SE

Marietta, GA 30067

R. F. Kaufman

Evaluation Branch

Office of Radiation Programs

U.S. Environmental Protection Agency

P. 0 . Box 18416

Las Vegas, NV 89114

Ralph Keh le

7800 Shoul Creek Blvd.

Suite 270 S

Aust in, TX 78757

Muzaffer Kehnemuy $i$

Office of Nuclear Waste Iso lation

Battelle Memorial Institute

$505 \mathrm{King}$ Ave.

Columbus, $\mathrm{OH} 43201$

John F. Kircher

Office of Nuclear Waste Isolation

Batte 11e Memorial Institute

505 King Ave.

Columbus, $\mathrm{OH} 43201$ 
No. of

Copies

Char les Koplick

The Analytic Sciences Corp.

6 Jacob Way

Reading, MA 01867

Char les W. Kreit ler

Texas Bureau of Economic Geo logy

University Station, Box $X$

Austin, TX 78712

George K. Kuk la

Lamont-Doherty Geological

Observatory

Palisades, NY 10964

Donald H. Kupfer

Department of Geology

Lou isianna State University

Baton Rouge, LA 70803

James G. LaBastie

Law Engineering and Testing Co.

2749 De lk Road SE

Marietta, GA 30067

Rona 1d B. Lantz

INTERA Environmental

Consultants, Inc.

11511 Katy Freeway

Houston, TX 77079

2 Lawrence Berkeley Laboratory

Reference Library

University of California

Berkeley, CA 94720

2 Lawrence Livermore Laboratory

Reference Library

P. 0. Box 808

Livermore, CA 94550

Darrelle I. Leap

USGS, WRD, MS416

Box 25046

Denver Federal Center

Denver, CO 80225
No. of

Copies

Richard Lincoln

Sandia Laboratories

N.N.W.S.I.

NTS Technical Overview

Division 4538

Albuquerque, NM 87185

Stan ley E. Logan

Nuc lear Waste Management Program

Los Alamos Technical

Associates, Inc.

P.0. Box 410

Los Alamos, NM 87554

Ear 1 M. Lovejoy

4400 Fairview Road

Reno, NV 89511

S. J. Mara

SRI Internationa 1

333 Ravenswood Avenue

Men 10 Park, CA 94025

Peter D. Mattison

Arthur D. Little, Inc.

Acorn Park

Cambridge, MA 02140

W. C. McClain

Oak Ridge National Laboratory

P.0. Box X

Oak Ridge, TN 37830

John T. McGinn is

Office of Nuclear Waste Isolation

Battelle Memorial Institute

505 King Ave.

Columbus, $\mathrm{OH} 43201$

She Idon Meyers

DOE Office of Nuclear Waste

Management

Washington DC 20545 
No. of

Copies

Peter A. Mote

Bechte 1, Inc.

P.0. Box 3965

San Francisco, CA 94105

2 Barry Naft

NUS Corporation

4 Research Place

Rockville, MD 20805

J. 0. Neff

Department of Energy

Columbus Program Office

505 King Ave.

Columbus, $\mathrm{OH} 43201$

Robert H. Neil

State of New Mexico

Environmental Evaluation Group

P.0. Box 968

Santa Fe, NM 87503

Ivars Neretnieks

Earth Science Division

Lawrence Berkeley Laboratory

University of California

Berkeley, CA 94720

2 Neil Norman

Environmental Sciences Dept.

Bechtel National, Inc.

P.0. Box 3965

San Francisco, CA 94105

2 Los Alamos Scientific Laboratory

Reference Library

P.0. Box 1663

Los Alamos, NM 87544

2 Oak Ridge National Laboratory

Central Research Library

Document Reference Section

Oak Ridge, TN 37830
No. of

Copies

Suresh B. Pahwar

INTERA Environmental

Consultants, Inc.

11511 Katy Freeway, Suite 630

Houston, TX 77079

Frank L. Parker

Dept. of Environmental

Engineering

Vanderbilt University

Nashville, TN 37235

James Pearson

INTERA Environmental

Consultants, Inc.

11511 Katy Freeway, Suite 630

Houston, TX 77079

George $F$. Pinder

Dept. of Civil Engineering

Stanford University

Stanford, CA 94305

Larry Ramspott

Technical Program Officer

Lawrence Livermore Laboratory

P. 0. Box 808

Livermore, CA 94550

Linda Robinson

NUS Corporation

4 Research Place

Rockville, MD 20850

Savannah River Laboratory

Reference Library

Aiken, SC 29801

Maurice L. Schwartz

Department of Geology

Western Washington University

Bellingham, WA 98225

Genevieve Segol

Bechte 1, Inc.

P. 0. Box 3965

San Francisco, CA 94105 
No. of

Copies

Herb Shaw

U.S. Geological Survey

Mail Stop 18

345 Midd lefield Road

Men 1o Park, CA 94025

Di11 ard B. Shipler

Office of Nuclear Waste

Iso lation

Battelle Memorial Institute

505 King Ave.

Columbus, $\mathrm{OH} 43201$

James N. Siltanen

Genera 1 Atomic Company

P.0. Box 81608

San Diego, CA 92138

George M. Slaughter

Law Engineering and Testing Co.

2749 Delk Road SE

Marietta, GA 30067

Barry J. Smernoff

Hudson Institute

Quaker Ridge Road

Croton-On-Hudson, NY 10520

Terry Ste inborn

Lawrence $L$ ivermore Laboratories

P.0. Box 808

Livermore, CA 94550

Howard $P$. Stephens

Sand ia Laboratories

N.N.W.S.I.

Division 4538

Albuquerque, NM 87185

James I. Stevens

Arthur D. Little, Inc.

Acorn Park

Cambridge, MA 02140

David B. Stewart

U.S. Geological Survey National

Center 959

Reston, VA 22092
No. of

Copies

Robert L. Thoms

Institute for Environmental

Studies

Louisianna State University

Baton Rouge, LA 70803

Newe 11 Trask

U.S. Department of the Interior Geological Survey

Mail Stop 929

Reston, VA 22092

W. S. Twenhofe1

USGS

Mai1 Stop 954

Denver, C0 80225

10 Maurice D. Veatch

6834 - 51st Ave. NE

Seatt le, WA 98115

W. Weart

Division 1140

Sandia Laboratories

Albuquerque, NM 87115

Lawrence Wight

TERA

2150 Shaltuck Ave.

Berkeley, CA 94704

Charlie Wilson

Earth Sciences Division

Lawrence Livermore Laboratory

Building 90

Berkeley, CA 94720

Paul Witherspoon

Earth Sciences Division

Lawrence Livermore Laboratory

Building 90

Berkeley, CA 94720 
No. of

Copies

FOREIGN

D'Al lessandro Avogadro
Commission of European
Commun ities
Joint Rersearch Centre
I-21020 Ispra (Varese)
ITALY

K. H. Hubentha 1

Bundesministerium fur Forschung und Technologie

Stressemannstrasse 2

Postf ach 200706

D-5300 Bonn

$F . R$. of GERMANY

Le if Carlsson

Geological Survey of Sweden

Bredgrand 4

S-753 20 UPPSALA

$018 / 15 \quad 56 \quad 40$

SWEDEN

Center for Atomic Energy Documentation (ZAED)

ATTN: Dr. Bell

Postf ach 3640

D-7500 Kar lsruhe

F.R. of GERMANY

Ken Dornuth

Atomic Energy Canada Ltd. Whiteshe 11 Nuclear Research Establishment

Pinawa, Manitoba ROE $1 \mathrm{LO}$

CANADA

F. Gera

Nuclear Energy Agency/OECD

38 boulevard Suchet

F-75016 Paris

FRANCE
No. of

Copies

2 INIS Clearinghouse

International Atomic Energy Agency

P.0. Box 590

A-1011, Vienna

AUSTRIA

K1 aus Kuhn

Institut fur Tiefagerung

Wissenschaftliche Abteilung

Berliner Strasse 2

D-3392 Clausthal - Zellerfeld

$F . R$. of GERMANY

Hans W. Levi

Hahn-Meitner-Institut fur Kernforschung

Glienicker Strasse 100

D-1000 Berlin 39

F.R. Of GERMANY

Library

Studsvik Energiteknik $A B$

S-611 01 Nykoping

SWEDEN

Takeh ico Ngamatsu

Geo log ist

Chief Representative Vancouver Office

Mitsubishi Metal Corporation

78 Granville Square

200 Granville Street

Vancouver, BC V6C 154

CANADA

Franz Peter Oesterle

Physikalisch-Chemische Bundesanstalt

Bundesallee 100

D-3300 Braunschweig

$F . R$. of GERMANY 
No. of

Copies

F. P. Sargent

Atomic Energy of Canada, Ltd.

Whiteshe 11 Nuclear Research

Establishment

Pinawa, Man itoba ROE 1 LO

CANADA

Nor itaka Sato

Chief Geologist, Domestic

Exploration \& Nuclear

Resources

Mitsub ishi Metal Corporation

1-5-2 Ohte-Machi

Chiyoda-Ku, tokyo

JAPAN

Egbert Schapermeier

Batte lle-Institute e.V.

Am Romerhof 35

D-6000 Frankfurt am Main 90

$F$. R. of GERMANY

Tjalle Vandergraff

Atomic Energy of Canada Limited

Whiteshe 11 Nuclear Research

$$
\text { Establishment }
$$

Pinawa, Manitoba ROE 1 LO

CANADA

\section{ONSITE}

5 Department of Energy

0. J. Elgert

H. E. Ransom

J. J. Schreiber

D. J. Squires

F. R. Standerfer
No. of

Copies

7 Rockwell Hanford Operations

R. L. Biggerstaff

D. J. Brown

R. A. Deju

G. S. Hunt

R. E. Isaacson

G. L. Jones

Rockwell Document Control

45 Pacific Northwest Laboratories

E. M. Arnold

G. L. Benson

A. Brandstetter (10)

R. A. Craig

W. J. Deutsch

F. H. Dove

M. A. Harwe 11

M. R. Kreiter

J. W. Lindberg

R. F. McCallum

K. S. Murthy

G. M. Petrie

A. M. Platt

J. F. Relyea

B. L. Scott

J. G. Stephan

J. A. Stott lemyre

R. W. Wallace

J. T. Zellmer

Technical Information Library

Publishing Coordination RO(2)

Water and Land Resources

Department Library (10) 